\title{
Faktor Produksi Usahatani Kelapa Dalam (Cocos nucifera Linn) pada Lahan Gambut di Kecamatan Kempas Kabupaten Indragiri Hilir
}

\author{
Khairizal*, Sisca Vaulin, Hajry Arief Wahyudy \\ Program Studi Agribisnis, Fakultas Pertanian, Universitas Islam Riau \\ * khairizal@agr.uir.ac.id
}

\begin{abstract}
Abstrak. Pada Kecamatan Kempas, kelapa tumbuh pada lahan gambut. Keadaan lahan tentunya akan menentukan jumlah produksi dan pendapatan yang akan diterima petani. Tujuan penelitian untuk mengetahui: (1) sarana produksi, biaya, pendapatan dan efisiensi petani kelapa dalam pada lahan gambut di Kecamatan Kempas; (2) faktor-faktor yang mempengaruhi produksi kelapa dalam pada lahan gambut di Kecamatan Kempas. Metode penelitian menggunakan metode survey. Penelitian dilakukan pada bulan april 2018-mei 2018. Hasil penelitian menunjukkan bahwa (1) produksi kelapa 4.008 butir/panen; sarana produksi yang digunakan oleh petani yaitu NPK, terusi, garam, herbisida; total biaya Rp 3.796.030; pendapatan bersih Rp 1.237.698 dan RCR 1,34. (2) Fungsi produksi Cocos nucifera kelapa dalam terhadap tenaga kerja dan terusi merupakan faktor yang tidak mempengaruhi produksi kelapa pada lahan gambut. Sedangkan luas lahan dan jumlah tanaman produktif mampu mempengaruhi produksi kelapa pada lahan gambut. Nilai koefisien determinasi $95 \%$..
\end{abstract}

Kata kunci: kelapa dalam, lahan gambut, produksi, pendapatan dan fungsi produksi

\section{PENDAHULUAN}

Tanaman kelapa (Cocos nucifera Linn.) dalam perekonomian Indonesia merupakan salah satu komoditi strategis karena perannya yang sangat besar, baik sebagai sumber pendapatan maupun sebagai sumber bahan baku industri. Uwubanmwen et al (2011), kelapa (Cocos nucifera L.) adalah salah satu pohon yang paling penting dan berguna di dunia, tanaman penting dalam ekonomi agraris di banyak daerah di dunia yang menyediakan makanan, minuman, tempat tinggal dan bahan baku untuk industri.

Palungkun (2001) kelapa dalam merupakan usahatani yang telah dikelola petani secara turun temurun pada berbagai daerah di Indonesia seperti: Aceh, Riau, Sumatra Utara, Lampung, Jawa Barat, Jawa Timur, Jawa Tengah, Sulawesi Utara, Sulawesi Selatan, Nusa Tenggara Timur, Maluku, dan Sulawesi Tengah. Sejak dulu, tanaman ini telah berkembang pesat sebagai sumber pendapatan yang diandalkan oleh petani. Direktorat Jendral Perkebunan (2017), Propinsi Riau terluas dan produksi terbesar di Indonesia, luas lahan $14,52 \%$ dan 13,90\% produksi kelapa Indonesia ada di Riau.

Kabupaten Indragiri Hilir sebagai kabupaten penghasil kelapa dalam terbesar di Propinsi Riau menyebabkan wilayah ini diberi slogan "hamparan kelapa dunia". Produksi kelapa dalam di wilayah kabupaten Indragiri Hilir mencapai 299.634 ton/tahun dengan luas lahan 392.461 hektar, Badan Pusat Statistik Indragiri Hilir (2016). Oleh sebab itu, potensi pengembangan kelapa dalam di daerah ini cukup besar, baik dilihat dari aspek budidaya, ekonomi, sosial maupun dari aspek budaya. Itulah sebabnya usahatani kelapa dalam sampai saat ini tetap dikembangkan oleh masyarakat setempat. Hal ini didukung pula dengan kebijakan pemerintah yang mendukung petani untuk tetap bertanam kelapa. Salah satu bentuk kontribusi pemerintah terhadap tanaman kelapa di kabupaten ini adalah (1) rehabilitasi, dan (2) intensifikasi.

Kesesuaian tanah di Kabupaten Indragiri Hilir terhadap tanaman kelapa berujung pada di setiap kecamatan terdapat tanaman kelapa. Abdurachman dan Anny (2003), dari segi tanahnya, kelapa dapat tumbuh dan berproduksi pada berbagai jenis tanah, baik tanah mineral maupun tanah organik (gambut). Di Kecamatan kempas, kelapa tumbuh pada lahan gambut. Hartawan, dkk (2017), produktivitas Kelapa Dalam lebih tinggi bila dibudidayakan pada lahan gambut. Perbedaan keadaan lahan tentunya akan berpengaruh

To cite this article: Khairizal, S. Vaulina, dan H.A. Wahyudy. 2019. Faktor Produksi Usahatani Kelapa Dalam (Cocos nucifera Linn) Pada Lahan Gambut di Kecamatan Kempas Kabupaten Indragiri Hilir. Unri Conference Series: Agriculture and Food Security 1: 142150. https://doi.org/10.31258/unricsagr.1a19 
pada jumlah produksi dan pendapatan yang akan diterima petani. Dengan berusahatani tanaman kelapa dalam jumlah yang lebih banyak serta melakukan perawatan yang benar, penghasilan yang kecil itu pasti akan meningkat. Oleh karena itu tingkat produksi tentulah dipengaruhi oleh berbagai faktor terutama tingkat penggunaan sarana produksi. Peningkatan produksi pada jumlah tertentu akan mempengaruhi motivasi petani dalam mengusahakan tanaman kelapa dalam secara kontinyu. Tujuan penelitian untuk mengetahui: (1) sarana produksi, biaya, pendapatan dan efisiensi petani kelapa dalam pada lahan gambut di Kecamatan Kempas; (2) faktor-faktor yang mempengaruhi produksi kelapa dalam pada lahan gambut di Kecamatan Kempas.

\section{METODE}

Penelitian ini menggunakan metode survei. Penelitian ini dilaksanakan di Kecamatan Kempas. Sampel pada penelitian ini ditentukan secara purposive sampling, yang didasarkan pada umur tanaman kelapa dengan kisaran 10-15 tahun. Kategori umur diambil sebagai sampel dengan pertimbangan bahwa umur tanaman kelapa menentukan tingkat produksi tanaman kelapa. Penentuan umur tanaman karena pada umur tersebut tanaman kelapa telah berproduksi maksimal. Dengan demikian, jumlah sampel penelitian berjumlah 25 orang.

\section{Analisis Data}

\section{Deskriptif Kuantatif}

Menghitung sarana produksi, biaya, pendapatan dan efisiensi petani kelapa dalam digunakan analisis deskriptif kuantitatif. Untuk mengetahui besarnya biaya yang dikeluarkan, digunakan perhitungan:

$$
\mathrm{TC}=\mathrm{FC}+\mathrm{VC}
$$

Keterangan:

$\mathrm{TC}=$ Total Cost (Biaya Total)

$\mathrm{FC}=$ Fixed Cost (Biaya Tetap)

$\mathrm{VC}=$ Variabel Cost (Biaya Variabel)

Menurut Soekartawi (2003), pendapatan usahatani adalah selisih antara jumlah penerimaan dan semua biaya.

Keterangan:

$$
\mathrm{Pd}=\mathrm{TR}-\mathrm{TC}
$$

$\mathrm{Pd}=$ Pendapatan Usaha Tani Kelapa

$\mathrm{TR}=$ Total Penerimaan

$\mathrm{TC}=$ Total Biaya

Sedangkan untuk menghitung penerimaan usahatani adalah produksi yang diperoleh dengan harga jual.

$$
\mathrm{TR}=\mathrm{Q} \times \mathrm{Pq}
$$

Keterangan:

$\mathrm{TR}=$ Total Revenue

$\mathrm{Q}=$ Jumlah produksi yang dijual

$\mathrm{Pq}=$ Harga kelapa per butir

Peralatan yang digunakan pada usahatani kelapa dalam umumnya tidak habis dipakai untuk satu kali periode produksi (lebih dari satu tahun). Oleh karena itu, biaya peralatan yang dihitung sebagai komponen biaya produksi adalah nilai penyusutannya. Untuk menghitung besarnya biaya penyusutan alat yang digunakan yakni metode garis lurus (straight line method) yang dikemukakan oleh Hernanto (1996), dengan rumus:

$$
\mathrm{D}=\frac{\mathrm{C}-\mathrm{SV}}{\mathrm{UL}}
$$

\section{Keterangan:}

$\mathrm{D}=$ Biaya penyusutan (Rp/unit/tahun)

$\mathrm{C}=$ Harga beli (Rp/unit/tahun)

$\mathrm{SV}=$ Nilai sisa $20 \%$ dari harga beli (Rp/unit/tahun) 
$\mathrm{UL}=$ Masa pakai alat (tahun)

\section{Fungsi Produksi Cocos nucifera}

Untuk menganalisis faktor-faktor yang mempengaruhi produksi kelapa dalam digunakan fungsi produksi Cocos nucifera. Model ini dipilih berdasarkan pertimbangan bahwa; (1) Model fungsi Cocos nucifera adalah model yang lazim digunakan dalam penelitian ekonomi pertanian karena sifatnya yang praktis dan mudah ditrasformasikan ke dalam bentuk linear (Soekartawi, 2003); (2) Menurut Gujarati (2001) koefisien regresi yang ditunjukkan oleh fungsi produksi Cocos nucifera merupakan elastisitas faktor produksi dan memberikan informasi mengenai pengaruh skala terhadap hasil (return to scale).

Pada dasarnya fungsi tersebut berasal dari regresi yang persamaan umumnya dapat ditulis sebagai berikut:

$$
\mathrm{Y}=\mathrm{f}(\mathrm{x})
$$

Keterangan:

$\mathrm{Y}=$ Variabel yang dipengaruhi (variabel terikat)

$\mathrm{x}=$ Variabel yang mempengaruhi (variabel bebas)

Sedangkan fungsi produksi Cocos nucifera secara matematis dapat ditulis sebagai berikut:

$$
Y_{i}=\beta_{0} \beta_{1} X_{21}^{\beta 2} X_{31}^{\beta 3} 1^{u i}
$$

Untuk menentukan faktor yang berpengaruh terhadap produksi kelapa dalam digunakan analisis kuantitatif melalui pendungaan Ordinary Least Square (OLS). Analisis ini dilakukan melalui pendekatan fungsi produksi bertipe Cocos nucifera yaitu suatu fungsi atau persamaan yang melibatkan dua variabel atau lebih, variabel yang satu disebut variabel independent $(\mathrm{Y})$ dan yang lain disebut variable dependent $(\mathrm{X})$ yang secara matematis formulasinya dapat dituliskan sebagai berikut:

$$
\mathrm{Y}=\mathrm{aX}_{1}{ }^{\mathrm{b} 1} \mathrm{X}_{2}{ }^{\mathrm{b} 2} \mathrm{X}_{3}^{\mathrm{b} 3} \mathrm{X}_{4}{ }^{\mathrm{b} 4} \mathrm{e}^{\mathrm{eu}}
$$

Agar fungsi produksi Cocos nucifera dapat diestimasi dengan metode OLS maka diubah ke dalam bentuk logaritma natural sebagai berikut:

$$
\operatorname{Ln} \mathrm{Y}=\mathrm{Lna}+\mathrm{b} 1 \mathrm{LnX} 1+\mathrm{b} 2 \operatorname{LnX} 2+\mathrm{b} 3 \operatorname{LnX} 3+\mathrm{b} 4 \operatorname{LnX} 4+\mathrm{u}
$$

dimana:

$\mathrm{Y}=$ Produksi kelapa dalam (Butir)

$\mathrm{X} 1$ = Lahan $(\mathrm{Ha})$

X 2 = Jumlah Tanaman Produktif (Batang)

$\mathrm{X} 3$ = Tenaga kerja $(\mathrm{HOK})$

$\mathrm{X} 4=$ Terusi $(\mathrm{Kg})$

Dengan asumsi bahwa, $\mathrm{E}$ (ui) $=0$, maka ei $=\mathrm{Y}($ yang diduga $)-\mathrm{Y}($ penduga $)$

\section{Pengujian Hipotesis secara Parsial (Uji t)}

Pengujian secara parsial menggunakan uji t yang merupakan uji pengaruh signifikan variabel independen terhadap variabel dependen secara individual. Uji signifikansi adalah prosedur di mana hasil sampel digunakan untuk menentukan keputusan untuk menerima atau menolak Ho berdasarkan nilai uji statistik yang diperoleh dari data. Prosedur dari uji t adalah sebagai berikut (Widarjono, 2007):

- Membuat hipotesa nol (Ho) dan hipotesa alternatif (Ha)

- Menghitung t dengan rumus:

dimana:

$$
\mathrm{t}_{\mathrm{hit}}=\frac{\mathrm{b}_{1}-\mathrm{b}}{\mathrm{S}_{\mathrm{b}}}
$$

bi $=$ Koefisien bebas ke-i

$\mathrm{b}=$ Nilai hipotesis nol

$\mathrm{Sb}=$ Simpangan baku (standar deviasi) dari variabel bebas ke-i

- Mencari nilai kritis t dari tabel $\mathrm{t}$ dengan $\mathrm{df}=\mathrm{n}-\mathrm{k}$ dan $\alpha$ yang tertentu

- Keputusan untuk menerima atau menolak Ho didasarkan pada perbandingan $t$ hitung dan $t$ tabel (nilai kritis).

Jika: $t$ hitung $>\mathrm{t}$ tabel, maka Ho ditolak dan Hi diterima

$\mathrm{t}$ hitung $<\mathrm{t}$ tabel, maka Ho diterima dan Hi ditolak 


\section{Pengujian Hipotesis secara Serempak (Uji F)}

Pengujian secara serempak menggunakan uji $\mathrm{F}$. Uji $\mathrm{F}$ bertujuan untuk menguji pengaruh semua variabel independen terhadap variabel dependen secara bersama-sama. Prosedur pengujian uji $\mathrm{F}$ adalah sebagai berikut:

- Membuat hipotesa nol (Ho) dan hipotesa alternatif (Ha)

- Menghitung nilai F.hitung dengan rumus:

$$
\mathrm{F}=\frac{\mathrm{R}^{2} /(\mathrm{k}-1)}{\left(1-\mathrm{R}^{2}\right) /(\mathrm{n}-\mathrm{k})}
$$

dimana:

$\mathrm{R}^{2}=$ Koefisien determinasi

$\mathrm{k}=$ Jumlah variabel independen

$\mathrm{n}=$ Jumlah sampel

- Mencari nilai kritis (F tabel); df (k-1, n-k).

dimana:

$\mathrm{k}=$ jumlah parameter termasuk intersep.

- Keputusan untuk menerima atau menolak Ho didasarkan pada perbandingan $\mathrm{F}$ hitung dan $\mathrm{F}$ tabel.

Jika: F hitung > F tabel, maka Ho ditolak dan Hi diterima. F hitung < F tabel, maka Ho diterima dan Hi ditolak.

\section{Koefisien Determinasi (R2)}

Koefisien determinasi adalah untuk mengetahui seberapa besar persentase sumbangan variabel bebas terhadap variabel terikat yang dapat dinyatakan dalam persentase. Besarnya persentase pengaruh semua variabel independen terhadap nilai variabel dependen dapat diketahui dari besarnya koefisien determinasi (R2) persamaan regresi. Besarnya koefisien determinasi berkisar antara nol sampai dengan satu. Semakin mendekati nol besarnya koefisien determinsi suatu persamaan regresi, maka semakin kecil pengaruh semua variabel independen terhadap variabel dependen. Sebaliknya, Semakin mendekati satu besarnya koefisien determinsi suatu persamaan regresi, maka semakin besar pengaruh semua variabel independen terhadap variabel dependen (Algifari, 2000).

\section{HASIL DAN PEMBAHASAN}

\section{Sarana Produksi, Biaya, Pendapatan dan Efisiensi Petani Kelapa Dalam pada Lahan Gambut di Kecamatan Kempas}

\section{Produksi}

Usaha peningkatan produksi sekarang ini bukan lagi semata-mata untuk peningkatan kuantitas hasil panen, tetapi ditujukan kepada peningkatan pendapatan petani. Oleh sebab itu petani sekarang lebih berorientasi terhadap harga. Produksi yang meningkat tanpa didukung oleh tingkat harga yang menguntungkan maka tidak akan memberikan jaminan bagi peningkatan pendapatan usahatani kelapa. Berikut disajikan tabel ratarata luas lahan, jumlah pohon dan produksi kelapa petani di Kecamatan Kempas.

Tabel 1. Rata-rata petani kelapa di kecamatan kempas berdasarkan luas lahan, jumlah pohon, produksi kelapa per produksi, tahun 2018

\begin{tabular}{ccc}
\hline Luas Lahan (Ha) & Jumlah Pohon & Produksi (Butir) \\
\hline 2,24 & 320 & 4.008 \\
\hline
\end{tabular}

Produksi kelapa yang dijadikan objek dalam penelitian ini adalah kelapa dalam bentuk butiran, dalam satu tahun produksi yaitu empat kali panen. berdasarkan hasil penelitian luas lahan rata-rata petani kelapa adalah 2,24 ha dan jumlah pohon 320 pohon dengan rata-rata produksi 4.008 butir dan rata-rata pohon kelapa yang dibudidayakan di lokasi penelitian sudah berbuah (produktif). 


\section{Biaya Produksi}

Biaya produksi turut menentukan tinggi rendahnya pendapatan, disamping besarnya produksi dan harga hasil produksi. Biaya produksi adalah keseluruhan biaya yang dikeluarkan selama proses produksi selama satu tahun, dalam hal ini produksi kelapa dalam bentuk butiran.

\section{a. Biaya Tetap}

Biaya tetap adalah biaya yang tidak tergantung dari besar kecilnya volume produksi. Dalam penelitian ini biaya tetap terdiri atas biaya penyusutan. Biaya penyusutan alat dihitung berdasarkan kepemilikan alat pertanian petani. Dalam penelitian ini peralatan yang akan dihitung penyusutannya adalah parang, cangkul, linggis, ambung, solak, handsprayer, pengait, dan tojok. Rata-rata usia ekonomis peralatan tersebut 3 tahun, kecuali solak yang memiliki umur ekonomis 5 tahun. Di Kecamatan Kempas berbeda dengan kecamatan yang lain di Kabupaten di Indragiri Hilir, yakni dalam hal penggunaan keranjang. Keranjang biasanya digunakan untuk mengangkut kelapa dari kebun ke tempat penjualan kelapa. Namun, di Kecamatan Kempas, sebagian petani menggunakan sungai untuk mengangkut kelapa. Untuk lebih jelas dapat dilihat Gambar 1.



Gambar 1. Petani menggunakan sungai untuk mengangkut kelapa

Kelapa yang sudah dipanen (masih bersabut), dimasukkan ke sungai dan dibawa ke ke rumah (sebagai tempat pengumpul kelapa). Hal ini dapat dilakukan apabila air laut dalam kondisi pasang. Untuk rata-rata biaya penyusutan kelapa sebesar Rp 128.161/tahun.

\section{b. Biaya Variabel}

\section{Bibit}

Rata-rata biaya bibit yang digunakan sebesar Rp 1.301.700, dengan harga bibit Rp 3.980/batang dan jumlah yang digunakan 320 batang. Bibit yang digunakan adalah bibit unggul, bibit berasal dari Kecamatan Pengalihan Enok dan Enok Dalam.

\section{Pupuk dan Pestisida}

Biaya variabel dalam hal ini yaitu biaya pupuk dan pestisida pada usahatani kelapa. Untuk usahatani kelapa umumnya petani menggunakan pupuk NPK, terusi, dan juga menggunakan garam. Sementara itu, untuk pestisida yang digunakan yaitu herbisida dan decis. Namun tidak semua petani yang menggunakan pestisida ini. Biaya yang dibutuhkan untuk penggunaan pupuk sebesar Rp 315.060/3 bulan dan biaya untuk penggunaan pestisida Rp 186.760/3 bulan. Pupuk dan pestisida yang diberikan petani saat 3 bulan sekali atau 4 bulan sekali atau 6 bulan sekali dan 1 tahun sekali. Namun, petani sampel kebanyakan memberikan pupuk dan pestisida 3 bulan sekali.

\section{Biaya Tenaga Kerja}

Sumber penggunaan tenaga kerja pada usahatani kelapa di daerah penelitian ada 2 yaitu: tenaga kerja dalam keluarga dan tenaga kerja luar keluarga (upahan). Biaya tenaga kerja terdiri atas: (1) pembersihan kebun atau penyiangan kebun kelapa; (2) pemupukan; (3) panen; dan (4) pengangkutan. Untuk tenaga kerja luar keluarga, upah yang diberikan untuk membersihkan kebun atau penyiangan kebun yaitu sebesar Rp 1.500/pohon - Rp 3.000/pohon. Tenaga kerja yang digunakan yaitu tenaga kerja wanita dan tenaga kerja 
pria. Total rata-rata biaya pembersihan kebun untuk luas lahan 2,24 ha dengan jumlah pohon kelapa 320 pohon maka biaya yang dibutuhkan untuk yaitu Rp 1.864.350/3bulan.

Masa kerja pembersihan kebun berkisar antara 7-8 jam masa pengerjaan, dimulai pagi pada pukul 07.0011.00 wib dan siang pada pukul 14.00-17.00 wib. Namun, ada juga petani yang mengerjakan hanya 3-4 jam pengerjaan dalam satu hari. Ini tidak begitu jadi persoalan bagi pemilik kebun, karena pembayaran upah yang diberikan berdasarkan jumlah pohon. Proses pembersihan kebun empat kali dalam setahun atau setara dengan proses produksi kelapa dalam satu tahun dengan biaya Rp 629.775.

Biaya pemupukan usahatani kelapa sebesar Rp 1.000/pohon-Rp 1.500/pohon, dengan total biaya pemupukan Rp159.975/3 bulan. Berdasarkan keterangan di lapangan, bahwa tidak semua daerah tanaman kelapa bagus diberi pupuk, contohnya di Kabupaten Tembilahan Hulu. Hal ini disebabkan karena tanah di daerah tersebut sudah subur dan sangat cocok untuk tanaman kelapa. Apabila diberi pupuk maka akan berpengaruh pada akar kelapa yakni akar cepat lapuk atau rapuh sehingga batang kelapa akan cepat tumbang. Oleh sebab itu, petani di daerah tersebut mayoritas tidak menggunakan pupuk hingga saat ini. Sementara itu, untuk biaya penyemprotan, dilakukan sendiri oleh petani.

Tabel 2. Rata-rata biaya produksi usahatani kelapa untuk satu kali panen di kecamatan kempas, tahun 2018

\begin{tabular}{lrr}
\hline \multicolumn{1}{c}{ Biaya Produksi } & Nilai (Rp) & Persentase (\%) \\
\hline A. Biaya Tetap & & \\
- Penyusutan alat & 128.161 & 3,38 \\
Jumlah Biaya Tetap & 128.161 & 3,38 \\
B. Biaya Variabel & & \\
- Bibit & 1.301 .700 & 34,29 \\
- Pupuk & 315.060 & 8,30 \\
- Pestisida & 186.760 & 4,92 \\
- Tenaga Kerja & & \\
Pembersihan kebun/penyiangan & 629.775 & 16,59 \\
Pemupukan & 159.975 & 4,21 \\
Panen & 729.675 & 19,22 \\
Pengangkutan & 344.925 & 9,09 \\
Jumlah Biaya Variabel & 3.667 .870 & 96,62 \\
Jumlah Biaya Produksi & 3.796 .030 & 100,00 \\
\hline
\end{tabular}

Biaya variabel panen usahatani kelapa, meliputi biaya mengait kelapa, mengumpulkan kelapa, dan pengupasan (memisahkan kelapa dari sabut). Upah panen di tempat penelitian dihitung beradasarkan jumlah butir kelapa yang telah dipanen. Upah panen ini bervariasi, dimulai dari Rp 100/butir. Dengan demikian, rata-rata biaya panen yang dikeluarkan oleh petani kelapa untuk satu kali proses produksi sebesar Rp 729.675/panen. Biaya pengangkutan hasil dari kebun bervariasi sesuai jarak yang akan di tempuh. Adapun rata-rata biaya pengangkutan dalam satu kali panen sebesar Rp 344.925.

Berdasarkan Tabel 2, dapat diperoleh informasi bahwa untuk usahatani kelapa menggunakan biaya tetap dalam satu kali panen dengan persentase 3,38\%, sedangkan untuk biaya variabel dengan persentase 96,62\%. Dilihat dari biaya variabel, maka biaya yang paling besar dikeluarkan adalah biaya bibit dengan persentase $34,29 \%$ dan biaya yang sedikit digunakan adalah biaya pemupukan dengan persentase $4,21 \%$.

Pendapatan

Harga merupakan persetujuan antara pembeli dan penjual dalam menilai suatu produk tertentu. Harga kelapa berdasarkan hasil penelitian bervariasi, dimulai dari harga $\mathrm{Rp} \mathrm{1.200/butir} \mathrm{hingga} \mathrm{Rp}$ 1.300/butir. Dalam hal ini, harga yang digunakan yaitu harga rata-rata dari 25 sampel petani kelapa yaitu Rp 1.240/butir. Pendapatan usahatani adalah selisih antara penerimaan dan semua biaya yang dikeluarkan dalam suatu usahatani. Secara rinci dapat dilihat pada Tabel 3.

Tabel 3. Rata-rata penerimaan dan pendapatan petani kelapa untuk satu kali panen di kecamatan kempas, tahun 2018

\begin{tabular}{clcc}
\hline No & & Uraian & Jumlah (Rp) \\
\hline 1 & Penerimaan & & 5.033 .728 \\
2 & Total biaya produksi & 3.796 .030 \\
3 & Pendapatan & 1.237 .698 \\
\hline
\end{tabular}


Berdasarkan Tabel 3, terlihat bahwa penerimaan yang diperoleh petani kelapa di Kecamatan Kempas sebesar Rp 5.033.728 dan total biaya produksi sebesar Rp 2.665.182,23. Dengan demikian, pendapatan yang diperoleh sebesar Rp 1.237.698/panen dengan luas lahan 2,24 ha dan jumlah produksi 4.008 butir/panen.

\section{Efisiensi}

Dalam penelitian ini hasil dari $\mathrm{R} / \mathrm{C}$ adalah rata-rata penerimaan petani dibagi dengan rata-rata biaya yang dikeluarkan oleh petani sehingga nilai R/C Ratio adalah 1,34. Hal ini berarti petani akan mendapatkan penerimaan sebesar Rp 1,34 untuk setiap 1 rupiah biaya yang dikeluarkan, dengan demikian usahatani kelapa di Kecamatan Kempas sudah layak.

\section{Faktor-Faktor yang Mempengaruhi Produksi Kelapa Dalam pada Lahan Gambut di Kecamatan Kempas}

Faktor-faktor yang mempengaruhi produksi kelapa dalam diperoleh berdasarkan hasil regresi dari data primer (sampel petani kelapa) yang diolah dengan menggunakan perangkat lunak SPSS versi 11.5, maka akan diperoleh persamaan regresi berganda yang kemudian ditransformasikan ke dalam persamaan fungsi produksi Cocos nucifera. Adapun yang menjadi variabel pada penelitian ini terdiri dari satu variabel terikat (dependent variable) dan delapan variabel bebas (independent variable). Variabel yang dijadikan unit analisis regresi berganda ini yakni; Y: Produksi kelapa dalam; X1: Lahan; X2: Jumlah tanaman produktif; X3: Tenaga kerja; X4: Terusi. Dengan persamaan sebagai berikut:

$$
\mathrm{LnQ}=\mathrm{Ln} 192,98+2.821,98 \mathrm{LnX} 1+(8,33) \mathrm{LnX} 2+18,85 \mathrm{LnX} 3+(31,92) \operatorname{LnX} 4
$$

Sehingga fungsi produksi dapat diperoleh sebagai berikut:

$$
\mathrm{Q}=192,98 \times 12.821,98 \times 2(8,33) \times 318,85 \times 4(31,92)
$$

\section{Uji Simultan (Uji F) Kelapa Dalam}

Pengaruh variabel bebas (Lahan; Jumlah tanaman produktif; Tenaga kerja; Terusi) secara serempak dapat dihitung dengan menggunakan uji F. Hasil pengujian dapat dilihat pada Tabel 4.

Tabel 4. Uji F kelapa dalam di kecamatan kempas, tahun 2018

\begin{tabular}{lrrrrr}
\hline & df & \multicolumn{1}{c}{ SS } & \multicolumn{1}{c}{ MS } & \multicolumn{1}{c}{ f } & Significance F \\
\hline Regression & 4,00 & $124.476 .442,84$ & $31.119 .110,71$ & 118,36 & 0,00 \\
Residual & 20,00 & $5.258 .236,52$ & $262.911,83$ & & \\
Total & 24,00 & $129.734 .679,36$ & & & \\
\hline
\end{tabular}

Berdasarkan Tabel 4 diperoleh nilai Fhitung sebesar 118,36 dengan tingkat kepercayaan 95\% $(\alpha=0,05)$, dilakukan pendekatan p-value atau sig., dimana sig. $<\alpha$, maka H0 ditolak dan $\mathrm{H} 1$ diterima artinya secara bersama-sama (serempak) variabel lahan; jumlah tanaman produktif; tenaga kerja; terusi berpengaruh signifikan terhadap produksi kelapa dalam di Kecamatan Kempas. Hasil ini menunjukkan bahwa faktor input produksi berpengaruh nyata terhadap produksi kelapa. Dengan kata lain bahwa tanpa adanya input produksi akan mengakibatkan terhentinya proses produksi dan hasil produksi sama dengan nol.

Hasil penelitian Damanik dan Dedi (2009) pada lahan gambut di Kecamatan Tempuling, Kabupaten Indragiri Hilir analisis fungsi produksi dengan tiga input faktor (bibit, pupuk dan tenaga kerja) menunjukkan bahwa posisi petani sebagai produsen berada pada kondisi yang artinya pemakaian input bibit, pupuk dan tenaga kerja masih dapat ditingkatkan untuk mencapai tingkat keuntungan yang maksimal. Sementara itu, Vaulina dan Saipul (2015), di Kabupaten Indragiri Hilir, luas lahan, jumlah tanaman menghasilkan, dan tenaga kerja merupakan faktor yang mempengaruhi produksi kelapa.

\section{Uji Parsial (Uji T) Kelapa Dalam}

Hasil uji pengaruh variabel lahan; jumlah tanaman produktif; tenaga kerja; terusi secara parsial dapat dilihat pada Tabel 5. Berdasarkan tabel tersebut terlihat bahwa variabel X1 (lahan) dan X2 (jumlah tanaman produktif) berpengaruh siginifikan terhadap variabel tak bebasnya (produksi kelapa dalam), sementara itu untuk variabel X3 (tenaga kerja) dan X4 (terusi) tidak berpengaruh signifikan terhadap variabel tak bebasnya (produksi kelapa dalam). 
Tabel 5. Uji T kelapa dalam di kecamatan kempas, tahun 2018

\begin{tabular}{crrrr}
\hline & Coefficients & Standard Error & t Stat & P-value \\
\hline Intercept & 192,98 & 285,50 & 0,68 & 0,51 \\
$\mathrm{X}_{1}$ & $2.821,98$ & 432,76 & 6,52 & 0,00 \\
$\mathrm{X}_{2}$ & $(8,33)$ & 2,99 & $(2,79)$ & 0,01 \\
$\mathrm{X}_{3}$ & 18,85 & 15,21 & 1,24 & 0,23 \\
$\mathrm{X}_{4}$ & $(31,92)$ & 51,47 & $(0,62)$ & 0,54 \\
\hline
\end{tabular}

\section{Pengaruh Lahan (X1) terhadap Produksi Kelapa Dalam}

Dari Tabel 5 terlihat untuk variabel $\ln \mathrm{X} 1$ (Lahan) diperoleh nilai thitung sebesar 6,52 dengan tingkat kepercayaan $95 \%(\alpha=0,05)$, maka dapat dikatakan variabel lahan (Ln X1) berpengaruh terhadap produksi kelapa dalam di Kecamatan Kempas. Variabel luas lahan berpengaruh terhadap produksi kelapa dikarenakan lahan yang dimiliki petani sampel umumnya memiliki lahan yang luas dengan rata-rata 2,24 ha. Luas lahan yang dimiliki petani mungkin saja sama namun populasi tanaman kelapa berbeda. Jarak tanam tiap petani kelapa berbeda, sehingga meskipun lahan sempit bisa ditanami pohon kelapa yang banyak.

\section{Pengaruh Jumlah Tanaman Produktif (X2) terhadap Produksi Kelapa Dalam}

Dari Tabel 5 terlihat untuk variabel ln X2 (Jumlah Tanaman Produktif) diperoleh nilai thitung sebesar $(2,79)$ dengan tingkat kepercayaan $95 \%(\alpha=0,05)$, maka dapat dikatakan variabel jumlah tanaman produktif (Ln X2) berpengaruh terhadap produksi kelapa dalam di Kecamatan Kempas. Jumlah tanaman produktif berpengaruh terhadap produksi kelapa dikarenakan populasi kelapa menentukan produksi. Apabila dalam satu tandan menghasilkan buah kelapa 15-20 butir, maka dalam satu batang kelapa bisa berbuah 2-4 tandan kelapa. Jika dikalikan dengan jumlah tanaman yang menghasilkan, akan meningkatkan produksi kelapa.

\section{Pengaruh Tenaga Kerja (X3) terhadap Produksi Kelapa Dalam}

Dari Tabel 5 terlihat untuk variabel $\ln \mathrm{X} 3$ (Tenaga kerja) diperoleh nilai thitung sebesar 1,24 dengan tingkat kepercayaan 95\% $(\alpha=0,05)$, dapat dikatakan variabel tenaga kerja ( $\operatorname{Ln}$ X3) tidak berpengaruh terhadap produksi kelapa dalam di Kecamatan Kempas. Tenaga kerja tidak berpengaruh terhadap produksi kelapa dikarenakan penggunaan tenaga kerja tidak banyak dibutuhkan pada saat budidaya kelapa. Misalnya pemupukan, petani umumnya memupuk ketika kelapa kurang produksinya. Selain itu, pemeliharaan kebun kelapa, tidak semua petani membersihkan kebun setiap hari.

\section{Pengaruh Pupuk (X4) terhadap Produksi Kelapa Dalam}

Dari Tabel 5 terlihat untuk variabel $\ln \mathrm{X} 4$ (Pupuk) diperoleh nilai thitung sebesar $-(0,62)$ dengan tingkat kepercayaan $95 \%(\alpha=0,05)$, dapat dikatakan variabel pupuk ( $\operatorname{Ln} \mathrm{X} 4)$ tidak berpengaruh terhadap produksi kelapa dalam di Kecamatan Kempas. Pupuk tidak berpengaruh terhadap produksi kelapa dikarenakan sebagian petani kelapa ada yang menggunakan pupuk yang sesuai anjuran, namun ada juga yang menggunakan pupuk ketika produksi kelapa menurun. Artinya bahwa menggunakan pupuk dan tidak menggunakan pupuk, kelapa tetap berbuah. Namun tingkat produksi dan lama berproduksi saja yang berbeda.

\section{Koefisien Determinasi (R2)}

Nilai koefisien determinasi (R2) sebesar 0,95 menunjukkan bahwa 95\% variasi lahan; jumlah tanaman produktif; tenaga kerja; dan pupuk mampu menjelaskan variasi produksi kelapa dalam, sedangkan sisanya 5\% dijelaskan oleh variabel lain yang tidak diteliti. Dengan kata lain, masih ada beberapa input produksi antara lain penggunaan bibit unggul dan pestisida yang dapat menjelaskan variasi produksi kelapa dalam. Damanik (2007), ketersediaan sumberdaya lahan dan iklim yang sesuai serta ketersediaan tenaga kerja dan teknologi begitu juga pangsa pasar, menjadi keunggulan untuk peningkatan produksi kelapa persatuan luas pengelolaan.

\section{KESIMPULAN}

Berdasarkan hasil penelitian di lapangan, maka dapat disimpulkan sebagai berikut:

1. Pendapatan petani kelapa sebesar Rp 1.237.698/panen, dengan luas lahan 2,24 Ha, jumlah pohon 320 batang dan produksi 4.008 butir. 
2. Berdasarkan analisis regresi linear berganda dari fungsi produksi Cocos nucifera, variabel lahan dan jumlah tanaman produktif mampu mempengaruhi produksi kelapa. Sedangkan tenaga kerja, dan pupuk tidak berpengaruh terhadap produksi kelapa dalam.

\section{DAFTAR PUSTAKA}

Abdurachman, dan A. Mulyani. 2003. Pemanfaatan Lahan Berpotensi untuk Pengembangan Produksi Kelapa. Jurnal Litbang Pertanian 22(1): 24-32.

Algifari. 2000. Analisis Regresi, Edisi Kedua. Yogyakarta: BPFE.

Badan Pusat Statistik Indragiri Hilir. 2016. Indragiri Hilir dalam Angka. Tembilahan: Kabupaten Indragiri Hilir.

Damanik, S. 2007. Strategi Pengembangan Agribisnis Kelapa (Cocos nucifera) untuk Meningkatkan Pendapatan Petani di Kabupaten Indragiri Hilir, Riau. Perspektif 6(2): 94-104.

Damanik, S., dan D.S. Effendi. 2009. Analisis Fungsi Produksi Usahatani Kelapa dan Respon Petani Kelapa di Kabupaten Indragiri Hilir. Buletin Palma 36: 62-75.

Gujarati. 2001. Ekonometrika Dasar. Jakarta: Erlangga.

Hartawan, R., Nasamsir., dan A. Gafur. 2017. Karakteristik Fisik dan Mutu Buah Kelapa Dalam (Cocos nucifera L) di Lahan Pasang Surut dan Lahan Gambut di Kabupaten Tanjung Jabung Barat. Jurnal Media Pertanian 2(1): 3746.

Palungkun, R. 2001. Aneka Produk Olahan Kelapa, Cetakan ke Sembilan. Jakarta: Penebar Swadaya.

Soekartawi. 2003. Teori Ekonomi Produksi dengan Pokok Bahasan Analisis Fungsi Cocos nucifera. Jakarta: PT. Raya Grafido Persada.

Uwubanmwen, I. O., C.N. Nwawe, R.A. Okere, M. Dada and E. Eseigbe. 2011. Harnessing the Potentials of the Coconut Palm in the Nigerian Economy. World Journal of Agricultural Sciences 7(6): 684-691.

Vaulina, S., dan S. Bahri. 2015. Produksi dan Pendapatan Petani Kelapa Dalam (Cocos nucifera Linn) di Kabupaten Indragiri Hilir Propinsi Riau. Prosiding Seminar Nasional Kristalisasi Paradigma Agribisnis dalam Pembangunan Ekonomi dan Pendidikan Tinggi. IPB International Convention Center-Bogor. Hal. 183-198.

Widarjono, A. 2007. Ekonometrika: Teori dan Aplikasi untuk Ekonomi dan Bisnis Edisi Kedua. Yogyakarta: Ekonisia Fakultas Ekonomi UII. 